\title{
Bioequivalence study of two Irbesartan/ Hydrochlorothiazide tablet formulations in Mexican healthy volunteers
}

\author{
Núñez-Guzmán NA ${ }^{1}$, Ruíz-Molina D ${ }^{1}$, Muñoz-Ibarra AI ${ }^{1}$, Figueroa-Núñez B ${ }^{1}$ and Almada-Alba J ${ }^{2}$ \\ ${ }^{1}$ Clínica de Enfermedades Crónicas y de Procedimientos Especiales, S.C. Morelia, Michoacán, México \\ ${ }^{2}$ Landsteiner Scientific S. A. de C. V., México
}

\begin{abstract}
Objective: To assess the bioequivalence of a new generic and a branded reference formulation of irbesartan/ hydrochlorothiazide $150 / 12.5$ mg tablets, in healthy Mexican volunteers.

Materials and methods: 36 male and female healthy volunteers participated in an open label, single dose, randomized-sequence, 2-way crossover study. Eligible subjects were randomly assigned (1:1) to receive a single 150/12.5 $\mathrm{mg}$ dose of either the test or reference formulations followed by a one week washout period. Blood samples were obtained before (sample control) and 0.34, 0.5, 0.75, 1.00, 1.50, 2.00, 2.50, 3.00, 5.00, 8.00, 12.0, 24.0, 36.0, 48.0 and 72.0 hours after dosing. Plasma concentrations of irbesartan and hydrochlorothiazide were analyzed by ultra-high resolution liquid chromatography coupled to a mass-mass detector.
\end{abstract}

Results: For irbesartan and hydrochlorothiazide, the $90 \%$ confidence intervals for $\mathrm{AUC}_{0-\mathrm{t}}, \mathrm{AUC}_{0-\infty}, \mathrm{C}_{\max }$ were within $80-125$ limits.

Conclusions: According to the Mexican regulations, it may be concluded that both formulations are bioequivalent.

\section{Introduction}

Globally cardiovascular disease accounts for approximately 17 million deaths a year, nearly one third of the total [1]. Of these, complications of hypertension account for 9.4 million deaths worldwide every year [2]. Hypertension is responsible for at least $45 \%$ of deaths due to heart disease, and $51 \%$ of deaths due to stroke [1]. A person over the age of 55 years has a $90 \%$ lifetime risk of developing hypertension [3].

In Mexico one of four adults have a diagnosis of hypertension (25.5\%) according to the National Health and Nutrition Survey 2016, weighted results [4].

Hypertension plays a major etiologic role in the development of cerebrovascular disease, ischemic heart disease, cardiac and renal failure [3]. Treating hypertension has been associated with about $40 \%$ reduction in the risk of stroke and about a $15 \%$ reduction in the risk of myocardial infarction [5].

In order to achieve significant reductions in the avoidable cardiovascular disease burden, a combination of population-based in high risk strategies is necessary. These strategies should target lifestylerelated risk factors such as unhealthy diet, physical inactivity and tobacco use, as well as the intermediate manifestations of this lifestyles; hypertension, glucose intolerance and hyperlipidemia [5].

The renin-angiotensin-aldosterone system (RAAS) is thought to be involved in the pathogenesis of isolated systolic hypertension by reducing the elastin content and increasing the collagen content of the arterial wall, thickening and fibrotic remodeling of the vascular intima, and inducing proliferation of arterial smooth-muscle cells, resulting in increased thickness, stiffening, and partial loss of contractility. Therefore, agents that block the RAAS, i.e., angiotensin receptor blockers (ARBs) or angiotensin-converting enzyme (ACE) inhibitors, provide the potential for beneficial effects on arterial stiffness in patients with isolated systolic hypertension that are independent of the agents' BP-lowering effects [6,7]

In 2014, the Eighth Joint National Committee (JNC 8) published the evidence-based guideline for the management of high blood pressure in adults, recommended for initial therapy for black should include a thiazide-type diuretic or a calcium channel blocker (including diabetic patients) and for nonblack patients (including diabetic patients) should include a thiazide-type diuretic, a calcium channel blocker, an angiotensin-converting enzyme (ACE) inhibitor, or an angiotensin receptor blocker [8].

Irbesartan is a potent and selective angiotensin II subtype 1 receptor antagonist indicated for use in patients with hypertension, including those with type 2 diabetes mellitus and nephropathy. Oncedaily administration of irbesartan provided 24-hour control of blood pressure [9].

Correspondence to: Dr. Núñez-Guzmán NA, Clínica de Enfermedades Crónicas y de Procedimientos Especiales, Fray Bernardino de Sahagún \#101, Fraccionamiento Mirador del Punhuato, Morelia, Michoacán, México, Tel: (01 443) 323 2828; E-mail: nora.nunez@cecype.com

Key words: bioequivalence, clinical trial, irbesartan hydrochlorothiazide

Received: April 28, 2017; Accepted: May 29, 2017; Published: May 31, 2017 
Hydrochlorothiazide belongs to a group of medicines called diuretics. Thiazide diuretics are particularly effective in preventing stroke and HF in hypertensive patients. These drugs are very effective in the elderly and very elderly patients [10].

These combinations has an additive antihypertensive effect, reducing blood pressure to a greater degree than either component alone [11].

The association of low-dosed diuretics in combination with RAAS blocking agents allows maximum benefit from potassium depletion and control of compensatory increase in renin secretion, so increasing the efficacy and safety of RAAS blockers. Irbesartan is a potent and selective angiotensin II subtype 1 receptor antagonist indicated for use in patients with hypertension, including those with type 2 diabetes mellitus and nephropathy [11].

The combination of the ARB irbesartan with the thiazide diuretic hydrochlorothiazide (HCTZ) has demonstrated efficacy and safety as initial therapy in patients with moderate and severe hypertension as well as in a broad range of patients who do not achieve BP goal on antihypertensive monotherapy $[12,13]$.

In Mexico there are few alternatives of drugs with this fixed combination, so it is very important to have generic products that meet the criteria of quality and effectiveness for this disease with high incidence in Mexican population.

\section{Materials and methods}

\section{Subjects}

The study was approved by the Research and Ethic Comittees and the Federal Commission for the Sanitary Risk Protection of Mexico (Comisión Federal de Protección contra Riesgos Sanitarios, COFEPRIS) [14]. It also followed the Good Clinical Practices Guidelines [15], the ethical principles for medical research for humans stated in the Declaration of Helsinki [16], the General Health Law of Mexico (Ley General de Salud, México) [17], and the Regulations of the General Health Law for Health Research (Reglamento de la ley General de Salud en Materia de Investigación para la Salud, México) [18]. Additionally, this study was conducted according to the Mexican Official Norm (NOM177-SSA1-2013) [19].

Thirty-six Mexican subjects were included in this clinical trial and were determined as healthy by clinical and laboratoy test. All of them were informed regarding the posible risks and adverse events after taking the study products. All the subjects gave their informed written consent to participate in the study.

\section{Study design}

This clinical trial was conducted according to an open, randomized, single-dose, crossover design, performing under fasting conditions, two periods, two sequences, with a washout period of seven days. The sample size was determined considering an expected power of $80 \%$ and the intra-subject variability of irbesartan/hydrochlorothiazide reported in the literature [20]. The test product was irbesartan/ hydrochlorothiazide tablets of $150 \mathrm{mg}$ and $12.5 \mathrm{mg}$ respectively (Landsteiner Scientific, S.A. de C.V., México [LP-BE15/004]), whereas the reference product was Coaprovel ${ }^{\oplus}$ (Sanofi-Aventis de México, S.A. de .C.V. [B4B617]). The administration of one tablet in two different periods. The sample schedule was $0.00,0.34,0.5,0.75,1.00,1.50,2.0$, $2.50,3.00,5.00,8.00,12.0,24.0,36.0,48.0$ and $72.0 \mathrm{~h}$ after the dose. The blood samples were obtained with heparin tubes, the plasma was separated by centrifugation $\left(2500 \mathrm{~g} \times 5 \mathrm{~min}\right.$ at $\left.4 \pm 2^{\circ} \mathrm{C}\right)$ and stored at a temperature below $-40^{\circ} \mathrm{C}$ until the analysis. The safety of the subjects was monitored during the whole study.

\section{Pharmacokinetics and statistical analysis}

Concentrations of drug plasmatic samples were obtained using an analitycal validated method by HPLC MS/MS.

Statistical analysis was performed with Phoenix WinNonlin ${ }^{\circledR} 6.3$ to determine pharmacokinetic values that establish the extent and rate of drug absorption. $\mathrm{C}_{\max }$ values $(\mathrm{ng} / \mathrm{mL})$ were obtained directly from experimentally observed data for each volunteer during the bioequivalence study. The AUC values $\left(h^{*} \mathrm{ng} / \mathrm{mL}\right)$ were also obtained using the WinNonlin ${ }^{\star} 6.3$ computer program by the trapezoid method. The elimination rate $(\mathrm{Ke})$ was calculated by log-linear regression of the final elimination phase $(\lambda)$, and the elimination half-life $\left(t_{1 / 2}\right)$ was calculated by dividing $\ln 2 / \mathrm{Ke}$. The area under the extrapolated curve at infinity $\left(\mathrm{AUC}_{0 \rightarrow \infty}\right)$ was determined by adding the quotient of the last measured concentration between Ke for each volunteer during the bioequivalence study to $\mathrm{AUC}_{0-\mathrm{t}}$.

Subsequently, to determine the bioequivalence by the Classical Confidence Interval (CI) the parameters $\mathrm{C}_{\max }, \mathrm{AUC}_{0-\mathrm{t}}$, and $\mathrm{AUC}_{0 \rightarrow \infty}$ of Hydrochlorothiazide and Irbesartan for formulations evaluated, the bioequivalence criteria was within $80-125 \%$.

\section{Results}

\section{Study population}

Thirty-six Mexican healthy volunteers (17 women and 19 men) were included in this study, aged between 20 and 50 years $(26.69 \pm$ $6.64)$, and body weight between 44 and $85 \mathrm{~kg}(62.40 \pm 10.74 \mathrm{~kg})$ body mass index was $24.0 \pm 2.7 \mathrm{~kg} / \mathrm{m}^{2}$.

\section{Pharmacokinetic analysis}

The next figures show the geometric mean plasma levels versus time of the arithmetic data and transformed semi-logarithmically for both drugs.

Results of the pharmacokinetics analysis after oral tablet administration of $12.5 \mathrm{mg}$ of hydrochlorothiazide and $150 \mathrm{mg}$ of irbesartan (reference and test product) in 35 subjects that completed the study are summarized in Table 1.

In Table 2 are shown the results of the $90 \%$ CI of the ratio of the geometric means considering the intrasubject variability. As observed, the values of the CI are within the range of acceptance (80 - 125\%).

\section{Discussion}

The final number of evaluated subjects was 35 , one volunteer was excluded because of receiving concomitant medication (itraconazole and miconazole) for the treatment of a non-serious adverse event not related to the study (dermatitis). A total of 22 non-serious adverse events were presented during the study.

The elimination half-life for hydrochlorotiazide was 9.57 and 9.69 for reference and test products, respectively. The washout period of 7 days was sufficient and no pre-dose concentration were showed. Time to reach maximum plasma concentration for hydrochlorotiazide observed was around $2 \mathrm{~h}$ and for irbesartan was $1.5 \mathrm{~h}$, the maximum plasma concentration for hydrochlorotiazide observed was around 125 $\mathrm{ng} / \mathrm{mL}$ and $2400 \mathrm{ng} / \mathrm{mL}$ for irbesartan. 

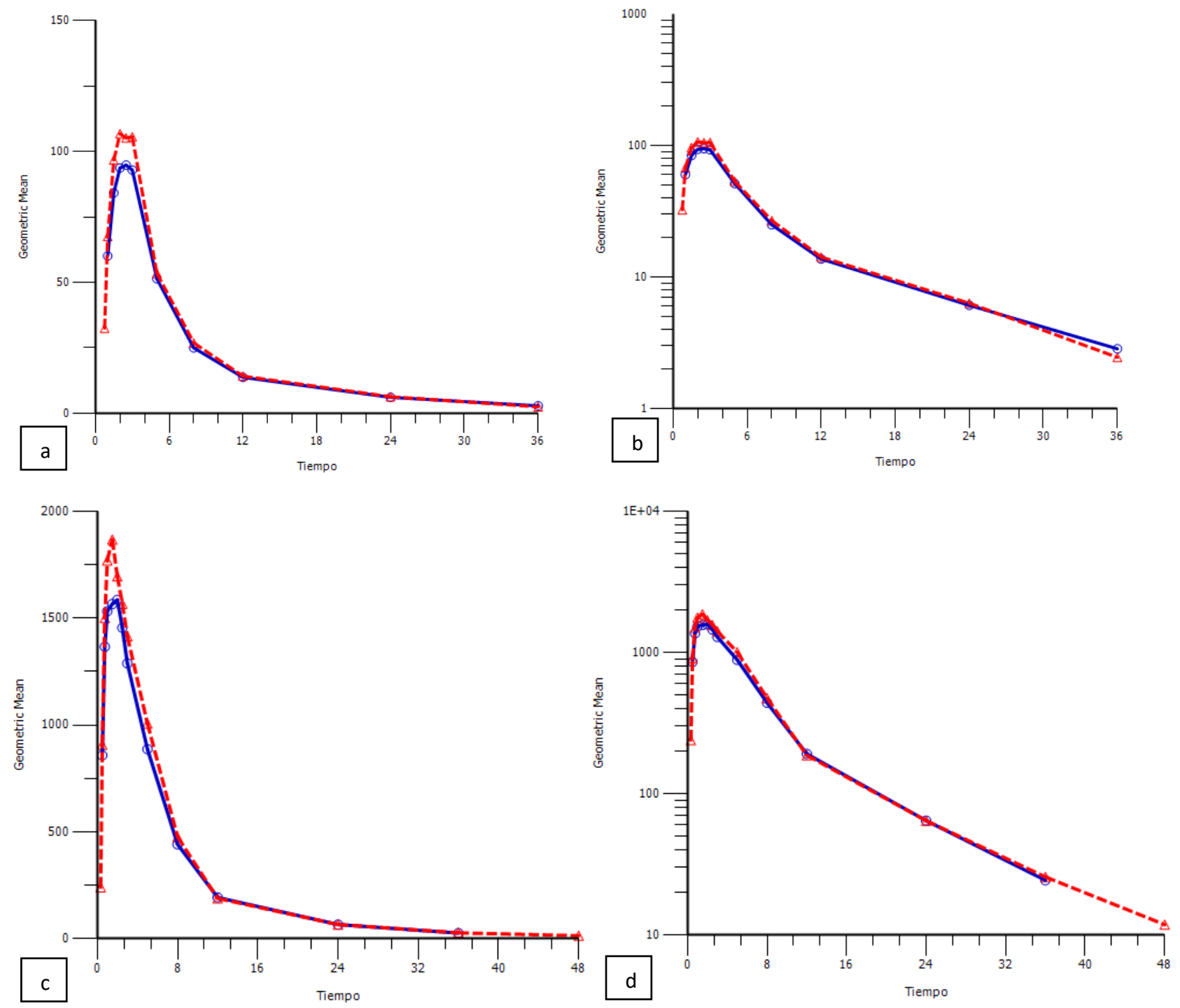

Figure 1. Geometric mean plasma levels of hydrochlorothiazide versus time in linear and semilogarithmic scale. (a) Geometric mean plasma levels of hydrochlorothiazide versus time in linear and (b) in semilogarithmic scale, following the administration of the test (red line) and reference products (blue line). Geometric mean plasma levels of irbesartan versus time in linear and semilogarithmic scale. (c) Geometric mean plasma levels of irbesartan versus time in linear and (d) in semilogarithmic scale, following the administration of the test (red line) and reference products (blue line).

Table 1. Pharmacokinetics parameters of hydrochlorothiazide and irbesartan

\begin{tabular}{|c|c|c|}
\hline \multicolumn{3}{|c|}{ Hydrochlorothiazide } \\
\hline Variable & Coaprovel $\mathbb{}$ & $\begin{array}{c}\text { Hydrochlorothiazide with } \\
\text { irbesartan }\end{array}$ \\
\hline $\mathrm{C}_{\text {max }}(\mathrm{ng} / \mathrm{mL})^{+}$ & $126.65(49.49)$ & $124.57(40.55)$ \\
\hline $\mathrm{AUC}_{0-\mathrm{t}}(\mathrm{ng} * \mathrm{~h} / \mathrm{mL})^{+}$ & $803.57(56.78)$ & $798.31(35.48)$ \\
\hline $\mathrm{AUC}_{0-\infty}(\mathrm{ng} * \mathrm{~h} / \mathrm{mL})^{+}$ & $777.03(34.76)$ & $823.06(34.82)$ \\
\hline $\mathrm{t}_{1 / 2}(\mathrm{~h})^{+}$ & $9.57(16.72)$ & $9.69(21.86)$ \\
\hline $\mathrm{t}_{\text {max }}^{++}$ & 2.50 & 2.00 \\
\hline & Irbesartan & \\
\hline $\mathrm{C}_{\text {max }}(\mathrm{ng} / \mathrm{mL})^{+}$ & $2455.08(36.89)$ & $2309.68(41.50)$ \\
\hline $\mathrm{AUC}_{0-\mathrm{t}}\left(\mathrm{ng}{ }^{+} \mathrm{h} / \mathrm{mL}\right)^{+}$ & $13279.16(41.62)$ & $13800.55(42.62)$ \\
\hline $\mathrm{AUC}_{0-\infty}(\mathrm{ng} * \mathrm{~h} / \mathrm{mL})^{+}$ & $13371.44(41.78)$ & $13936.50(42.82)$ \\
\hline $\mathrm{t}_{1 / 2}(\mathrm{~h})^{+}$ & $9.26(36.84)$ & $10.32(39.18)$ \\
\hline $\mathrm{t}_{\text {max }}^{+}$ & 1.50 & 1.50 \\
\hline
\end{tabular}

+ Geometric mean, $(\mathrm{CV} \%$ Geometric Mean)

++ Median

$\mathrm{n}=35$
The limits of $90 \%$ CIs for ratios of $\mathrm{C}_{\max }, \mathrm{AUC}_{0-\mathrm{t}}$ and $\mathrm{AUC}_{0-\infty}$ for their log-transformed data fell within 80 to 125 as given in table 2, both formulations are statistically equal in terms of rate and extent of absorption, so the bioequivalence between both formulations can be concluded.

The analysis of variance for all the analyzed parameters showed no significant differences for irbesartan and only AUC's for hydrochlorotiazide showed effect in sequence, nevertheless, no predose concentration were obtained in second session.

\section{Conclusions}

With the results obtained it was concluded that the test product is bioequivalent to the reference formulation according to Mexican and world regulations because the $90 \%$ CIs are within the acceptance range of $80-125 \%$. 
Table 2. $90 \% \mathrm{CI}$ of $\mathrm{C}_{\max }, \mathrm{AUC}_{0-\mathrm{t}}$ and $\mathrm{AUC}_{0-\infty}$

\begin{tabular}{|c|c|c|}
\hline $\begin{array}{c}\text { Pharmacokinetic } \\
\text { parameters }\end{array}$ & $\begin{array}{c}\mathbf{9 0 \%} \text { CI of the ratio test/ } \\
\text { reference }\end{array}$ & $\begin{array}{c}\text { Intrasubject CV } \\
\text { (\%) }\end{array}$ \\
\hline & Hydrochlorothiazide \\
\hline $\mathrm{Ln}_{\text {max }}(\mathrm{ng} / \mathrm{mL})$ & $87.5180-111.4038$ & 30.38 \\
\hline $\mathrm{Ln} \mathrm{AUC}_{0-\mathrm{t}}(\mathrm{ng} * \mathrm{~h} / \mathrm{mL})$ & $87.8172-113.1077$ & 31.94 \\
\hline $\mathrm{Ln} \mathrm{AUC}_{0-\infty}(\mathrm{ng} * \mathrm{~h} / \mathrm{mL})$ & $100.6860-110.8311$ & 11.72 \\
\hline \multicolumn{3}{|c|}{ Irbesartan } \\
\hline $\mathrm{Ln} \mathrm{C}_{\text {max }}(\mathrm{ng} / \mathrm{mL})$ & $86.7827-102.3793$ & 20.56 \\
\hline $\mathrm{Ln} \mathrm{AUC}_{0-\mathrm{t}}(\mathrm{ng} * \mathrm{~h} / \mathrm{mL})$ & $97.5541-110.3395$ & 15.25 \\
\hline $\mathrm{Ln} \mathrm{AUC}_{0-\infty}(\mathrm{ng} * \mathrm{~h} / \mathrm{mL})$ & $97.6872-110.7788$ & 15.58 \\
\hline
\end{tabular}

\section{Acknowledgments}

The authors and the trial staff both contributed to the manuscript. The authors acknowledge the staff of Clinica de Enfermedades Crónicas y de Procedimientos Especiales (CECYPE). All named authors meet the International Committee of Medical Journal Editors criteria for authorship for this manuscript, take responsibility for the integrity of the work as a whole, and have given final approval of the version to be published.

\section{Funding information}

This study was performed entirely by CECYPE and was supported by Landsteiner Scientific, S.A. de C.V. Mexico.

\section{Conflict of interest}

Nora Angélica Núñez Guzmán, Daniel Ruiz Molina, Adriana Ivett Muñoz Ibarra, Benigno Figueroa Núñez are employed by CECYPE and declare no conflicts of interest.

Jorge Almada Alba is employee of Landsteiner Scientific, S.A. de C.V. and receives a salary of the organization. He does not hold any stocks or shares in an organization that may gain or lose financially from the publication of this manuscript. The organization is not financing this manuscript.

\section{Ethics approval and consent to participate}

All procedures followed were in accordance with the ethical standards of the responsible committee on human experimentation (institutional and national) and with the Declaration of Helsinki. Informed consent was obtained from all subjects included in the clinical trial.

\section{References}

1. Causes of Death (2008) Geneva, World Health Organization (http?://www.who.int/ healthinfo/global_burden_disease/cod_2008_sources_methods.pdf)

2. Lim SS, Vos T, Flaxman AD, Danaei G, et al. (2012) A comparative risk assessment of burden of disease and injury attributable to 67 risk factors and risk factor clusters in 21 regions, 1990-2010: a systematic analysis for the Global Burden of Disease Study 2010. Lancet 380: 2224-2260
3. Vasan RS, Beiser A, Seshadri S, Larson MG, Kannel WB, et al. (2002) Residual lifetime risk for developing hypertension in middle-aged women and men: The Framingham Heart Study. JAMA. 287: 1003-1010.

4. National Institute of Public Health. National Half-Way Health and Nutrition Survey 2016 Final Results Report (Instituto Nacional de Salud Pública. Encuesta Nacional de Salud y Nutrición de Medio Camino 2016 Informe Final de Resultados)

5. Whitworth JA1; World Health Organization, International Society of Hypertension Writing Group (2003) 2003 World Health Organization (WHO)/International Society of Hypertension (ISH) statement on management of hypertension. J Hypertens 21: 1983-1992. [crossref]

6. Volpe M (2005) Treatment of systolic hypertension: spotlight on recent studies with angiotensin II antagonists. J Hum Hypertens 19: 93-102. [crossref]

7. Chrysant SG (1998) Vascular remodeling: the role of angiotensin-converting enzyme inhibitors. Am Heart J 135: S21-S30. [crossref]

8. James PA, Oparil S, Carter BL, Cushman WC, Dennison-Himmelfarb C, et al. (2014) 2014 evidence-based guideline for the management of high blood pressure in adults: report from the panel members appointed to the Eighth Joint National Committee (JNC 8). JAMA 311: 507-520.

9. Croom KF, Curran MP, Goa KL, Perry CM (2004) Irbesartan: a review of its use in hypertension and in the management of diabetic nephropathy. Drugs 64: 999-1028. [crossref]

10. Ehud Grossman, Paolo Verdecchia, Ari Shamiss, Fabio Angeli, Gianpaolo Reboldi (2011) Diuretic Treatment of Hypertension. Diabetes Care 34(Suppl 2): S313-S319. [crossref]

11. Derosa G, Ferrari I, Cicero AF (2009) Irbesartan and hydrochlorothiazide association in the treatment of hypertension. Curr Vasc Pharmacol 7: 120-136. [crossref]

12. Kochar M, Guthrie R, Triscari J, Kassler-Taub K, Reeves RA (1999) Matrix study of irbesartan with hydrochlorothiazide in mild-to-moderate hypertension. Am J Hypertens 12: 797-805. [crossref]

13. Neutel JM, Franklin SS, Oparil S (2006) Efficacy and safety of irbesartan/HCTZ combination therapy as initial treatment for rapid control of severe hypertension. $J$ Clin Hypertens (Greenwich) 8: 850-857. [crossref]

14. Federal Commission for the Protection of Sanitary Risks, Mexico (Comisión Federal para la Protección de Riesgos Sanitarios, México- COFEPRIS).

15. International Conference on Harmonisation of Technical Requirements for Registration of Pharmaceuticals for Human Use. ICH harmonised tripartite guideline: guideline for good clinical practice E6(R1), June 1996.

16. Ethical principles for medical research in humans of the Declaration of Helsinki issued by the 64th General Assembly, Fortaleza, Brazil, October 2013.

17. General Health Law of Mexico (Ley General de Salud, México).

18. Regulations of the General Health Law for Health Research (Reglamento de la Ley General de Salud en Materia de Investigación para la Salud, México).

19. Norma O?cial Mexicana NOM-177-SSA1-2013. Que establece las pruebas y procedimientos para demostrar que un medicamento es intercambiable. Requisitos a que deben sujetarse los Terceros Autorizados que realicen las pruebas de intercambiabilidad. Requisitos para realizar los estudios de biocomparabilidad. Requisitos a que deben sujetarse los Terceros Autorizados, Centros de Investigación o Instituciones Hospitalarias que realicen las pruebas de biocomparabilidad.

20. Sasongko L, Harahap Y, Prasaja B, Lusthom W, Setiawan EC, et al. (2010) Comparative bioavailability of two irbesartan/hydrochlorothiazide tablet formulations in Indonesian healthy subjects. Arzneimittelforschung 60: 749-753. [crossref]

Copyright: (C2017 Núñez-Guzmán NA. This is an open-access article distributed under the terms of the Creative Commons Attribution License, which permits unrestricted use, distribution, and reproduction in any medium, provided the original author and source are credited. 